\title{
PECULARITIES OF THE DERMATOGLYPHICS OF THE FINGERS OF THE FEMALE POPULATION OF THE HUTSUL ETHNIC GROUP
}

\begin{abstract}
N.M. Kozan'
Abstract. The paper presents the results of studies of the finger dermatoglyphics of the hands of females, belonging to the Hutsul ethnic group, living on the territory of a Ivano-Frankivsk region, and persons of the female gender of Ukrainian nationality, natives of other regions of Ukraine. Based on the research carried out by the author factor criteria were defined, differentiating the mentioned groups (the frequency and the specific characteristics of the patterns distribution on various fingers of the hands of one person).
\end{abstract}

Key words: forensic medicine, dermatoglyphics, personal identification

SHEE «National Medical University» (Ivano-Frankivsk)

Рецензент - проф. В.Т. Бачинський

Buk. Med. Herald. - 2013. - Vol. 17, № 3 (67), part 1. - P. 74-76

Надійшла до редакції 08.05.2013 року

\section{(C) Н.М. Козань, 2013 \\ УДК 616.718-001.5-073:340.6 \\ В.Л. Колесников \\ ЭКСПЕРТИЗА ЧЕРЕПНО-МОЗГОВОЙ ТРАВМЫ НА ФОНЕ ПРЕДШЕСТВУЮЩИХ ЗАБОЛЕВАНИЙ}

Николаевское областное бюро судебно-медицинской экспертизы

\footnotetext{
Резюме. Черепно-мозговая травма у лиц, страдающих хроническими заболеваниями, имеет особенности, которые усложняют проведение экспертиз и могут повлечь ошибку в экспертной оценке.
}

Ключевые слова: экспертиза закрытой черепномозговой травмы (ЗЧМТ), хроническая патология.
Анализ случаев (17 наблюдений) закрытой черепно-мозговой травмы в виде сотрясения или контузии головного мозга легкой степени, произошедшей на фоне хронических заболеваний, показал, что они имеют общие признаки:

a) часто отсутствуют объективные данные, свидетельствующие о потере сознания при травме; б) нередко свидетельствуемые описывают обстоятельства, что говорит об отсутствии ретроградной амнезии; в) имеет место позднее обращение за медицинской помощью, при нескольких обращениях - наблюдается нарастание описываемых симптомов при каждом последующем обращении; г) в анамнезе жизни отсутствуют указания на перенесенные в прошлом черепномозговые травмы, сосудистые заболевания и т.п.; д) среди описываемых клиницистами симптомов преобладают субъективные - жалобы на слабость, головную боль, тошноту, указание на потерю сознания, объективно отмечается неточность в выполнении пальценосовой пробы, шаткость в позе Ромберга, горизонтальный нистагм, симптом Гуровича-Манна, нарушение конвергенции; е) при КТ и МРТ исследованиях вскоре после травмы наблюдаются изменения паутинных оболочек, признаки гидроцефалии, наличие мелких очагов обызвествления, явления поражения шейного отдела позвоночника; ж) преобладает вегететивная и психопатическая симптоматика в виде (с) В.Л. Колесников, 2013 ранней астенизации, ощущения тревоги, страхов, акцентирования собственного состояния, эмоциональной лабильности, чувства «жара» и т.п.; з) течение заболевания носит характер плато или симптомы нарастают, затем стабилизируются, без заметной положительной динамики на фоне проводимого лечения.

Типичный пример. Мужчина 69 лет поступил в отделение нейрохирургии через сутки после травмы с жалобами на слабость, головокружение, шум в ушах, тошноту, наличие раны в лобной области . АД 160/100 мм рт. ст. Фотореакции вялые, шаткость в позе Ромберга, неуверенная пальценосовая проба. Тремор век и пальцев рук. На ЭЭГ - косвенные признаки ликворной гипертензии и очаговых изменений. Диагноз: сотрясение головного мозга, ушибленная рана лба. Выписан на 11-ые сутки с некоторым улучшением. На следующий день поступает в отделение неврологии с жалобами на головную боль в теменно-затылочной области, чувство давления на глаза, шум в голове, плохой сон, утомляемость. Астеничен, лабилен, тревожен. Болезненность глазных яблок, слабость конвергенции. Болезненность в области затылочных точек. Симптом Кернига положителен с обеих сторон. В позе Ромберга пошатывание. Симптом ГуровичаМанна положительный. Клинический диагноз: состояние после перенесенного сотрясения голо- 
вного мозга, посттравматическая церебростения, стойкий цефалгический синдром, гипертензионно-ликворный синдром. Выписан на 14-ый день с некоторым улучшением. В заключении эксперта повреждения отнесены к категории средней степени тяжести по критерию длительности расстройства здоровья. Через 10 месяцев по тем же документам другой эксперт повреждения расценивает, как легкие, повлекшие кратковременное расстройство здоровья, но не приводит обоснование вывода. На комиссионную экспертизу с участием нейрохирурга дополнительно затребованы медицинские документы, из которых стало известно, что свидетельствуемый страдает атеросклерозом с недостаточностью кровообращения и хроническим нарушением мозгового кровобращения в течение 8 лет, четыре года назад устанавливается диагноз гипертоническая болезнь, окулистом на глазном дне описаны изменения, характерные для длительного гипертензионного синдрома. Изучив представленные данные, комиссия пришла к выводам, что у потерпевшего имело место сотрясение головного мозга, т.е. легкое телесное повреждение, повлекшее кратковременное расстройство здоровья. Эта травма обострила имевшиеся фоновые заболевания, утяжелила их течение и привела к удлинению сроков выздоровления, что не может изменить оценку степени тяжести телесных повреждений (норма п.4.7 «Правил судебно-медицинского определения степени тяжести телесных повреждений», утвержденных приказом MO3 Украины №6 от 17.01.1995 г.).

\section{Выводы}

1. Изменение первичных экспертных заключений в случаях черепно-мозговой травмы, произошедшей на фоне имевшихся хронических заболеваний, свидетельствует о надостаточном внимании судебно-медицинских экспертов к этому вопросу.

2. Причиной ошибочных первичных заключений является формальный подход к решению вопроса, когда не анализируются симптомы, результаты инструментальных исследований, не укладывающиеся в классическую картину черепно-мозговой травмы.

3. В случаях, когда клиника закрытой черепно-мозговой травмы не укладывается в типичную картину, необходимо изучать медицинскую документацию периода до травмы, в ряде случаев требовать проведения дополнительных, в том числе инстументальных, обследований и шире привлекать для решения вопроса врачейспециалистов соответствующего профиля.

\section{Литература}

1. Сотрясения головного мозга / Б.А. Саркисян, Н.В. Бастуев, И.В. Паньков, В.С. Трубченков. Монография. - Новосибирск: Наука. Сибирская издательская фирма РАН, 2000. $-245 \mathrm{c}$.

2. Гришко В. И. Экспертиза телесных повреждений при сотрясении мозга у лиц с предшествующими заболеваниями нервной системы или травмами головы / В.И. Гришко // Вопр. суд. мед. и эксперт. практики. Чита, 1973. - № 5. - С. 123-125.

3. Емельянова Е.К. Черепно-мозговая травма у лиц с патологией центральной нервной системы / Е.К. Емельянова, О.В. Трейер, В.П. Конев // СМЖ (Томск). 2008. - № 1-1.

\section{ЕКСПЕРТИЗА ЧЕРЕПНО-МОЗКОВОЇ ТРАВМИ НА ТЛІ ПОПЕРЕДНІХ ЗАХВОРЮВАНЬ}

\section{В.Л. Колесніков}

Резюме. Черепно-мозкова травма (ЧМТ), яка виникла на тлі хронічної патології, має особливості, які ускладнюють провадження експертиз та можуть призвести до помилкового експертного рішення.

Ключові слова: експертиза закритої черепно-мозкової травми (ЗЧМТ), хронічна патологія

\section{EXAMINATION OF CRANIOCEREBRAL INJURY AGAINST A BACKGROUND OF PRIOR DISEASES}

\section{V.L. Kolesnikov}

Abstract. A craniocerebral injury (CCI) that arose against a background of chronic pathology has specific characteristics, complicating the performance of forensic-medical examinations and may result in an erroneous expert's conclusion.

Key words: examination of closed craniocerebral injury (CCCI), chronic pathology.

Regional Bureau of Forensic-Medical Examination (Nikolayev) 